\section{BRAZIULIAN JOURNAL}

OF MEDICAL AND BIOLOGICAL RESFARCH

www.bjournal.com.br
ISSN 0100-879X

Volume 43 (3) 182-267 March 2011

BIOMEDICAL SCIENCES

AND

CLINICAL INVESTIGATION

Braz J Med Biol Res, March 2011, Volume 44(3) 182-185

doi: 10.1590/S0100-879X2011007500004

Evidence for the endophytic colonization of Phaseolus vulgaris (common bean) roots by the diazotroph Herbaspirillum seropedicae

M.A. Schmidt, E.M. Souza, V. Baura, R. Wassem, M.G. Yates, F.O. Pedrosa and R.A. Monteiro

The Brazilian Journal of Medical and Biological Research is partially financed by

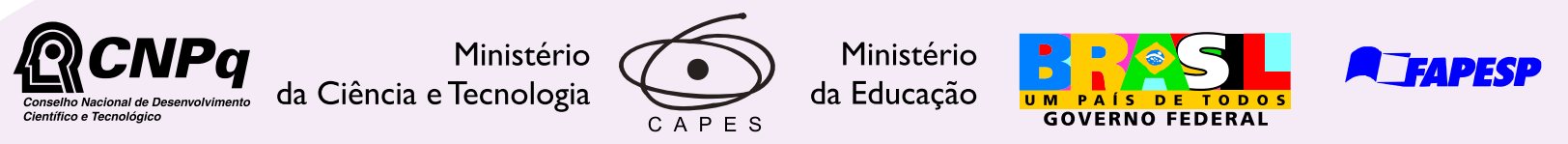

Institutional Sponsors
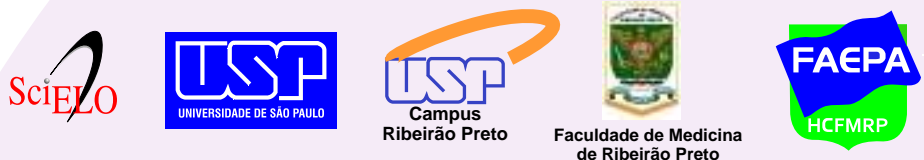


\title{
Evidence for the endophytic colonization of Phaseolus vulgaris (common bean) roots by the diazotroph Herbaspirillum seropedicae
}

\author{
M.A. Schmidt ${ }^{1}$, E.M. Souza ${ }^{1}$, V. Baura ${ }^{1}$, R. Wassem², M.G. Yates ${ }^{1}$, \\ F.O. Pedrosa ${ }^{1}$ and R.A. Monteiro ${ }^{1}$ \\ ${ }^{1}$ Departamento de Bioquímica e Biologia Molecular, ${ }^{2}$ Departamento de Genética, \\ Universidade Federal do Paraná, Curitiba, PR, Brasil
}

\begin{abstract}
Herbaspirillum seropedicae is an endophytic diazotrophic bacterium, which associates with important agricultural plants. In the present study, we have investigated the attachment to and internal colonization of Phaseolus vulgaris roots by the $H$. seropedicae wild-type strain SMR1 and by a strain of $H$. seropedicae expressing a red fluorescent protein (DsRed) to track the bacterium in the plant tissues. Two-day-old $P$. vulgaris roots were incubated at $30^{\circ} \mathrm{C}$ for $15 \mathrm{~min}$ with $6 \times 10^{8} \mathrm{CFU} / \mathrm{mL} H$. seropedicae SMR 1 or RAM4. Three days after inoculation, $4 \times 10^{4}$ cells of endophytic $H$. seropedicae SMR1 were recovered per gram of fresh root, and 9 days after inoculation the number of endophytes increased to $4 \times 10^{6} \mathrm{CFU} / \mathrm{g}$. The identity of the recovered bacteria was confirmed by amplification and sequencing of the 16SrRNA gene. Furthermore, confocal microscopy of $P$. vulgaris roots inoculated with $H$. seropedicae RAM4 showed that the bacterial cells were attached to the root surface 15 min after inoculation; fluorescent bacteria were visible in the internal tissues after $24 \mathrm{~h}$ and were found in the central cylinder after $72 \mathrm{~h}$, showing that $H$. seropedicae RAM4 is capable of colonizing the roots of the dicotyledon $P$. vulgaris. Determination of dry weight of common bean inoculated with $H$. seropedicae SMR1 suggested that this bacterium has a negative effect on the growth of $P$. vulgaris.
\end{abstract}

Key words: Herbaspirillum seropedicae; Phaseolus vulgaris; Confocal microscopy

\section{Introduction}

Herbaspirillum seropedicae is a diazotrophic endophyte of the $\beta$-proteobacteria (1), which colonizes internal tissues of maize, rice, wheat, sorghum, and sugar cane $(2,3)$. This organism has also been isolated from plants other than Poaceae such as banana and pineapple $(4,5)$. H. seropedicae may stimulate plant growth by supplying fixed nitrogen to the plant, producing and secreting phytohormones or protecting the host against pathogenic microorganisms $(6,7)$. The bacterial association with poaceous crops apparently initiates with attachment to root surfaces followed by proliferation at the emergence points of secondary roots and penetration through discontinuities in the epidermis. Rapid occupation of root intercellular spaces then occurs, and the bacteria spread to aerenchyma, xylem vessels and aerial portions (8-10).

Olivares et al. (11) described the isolation of $H$. seropedicae from gramineae and also from roots of a legume species (Cajanus cajan). However, the authors suspected that fragments of maize roots might have contaminated the legume sample.
Later, Valverde et al. (12) isolated a new species of this genus from the nodules of Phaseolus vulgaris. Based on genotypic and phenotypic characterization, the new isolates were classified as a novel species for which the authors proposed the name $H$. lusitanum sp nov.

The aim of the present study was to determine if $H$. seropedicae is able to establish an endophytic relationship with P. vulgaris.

\section{Material and Methods}

$H$. seropedicae SMR1 is a spontaneous streptomycinresistant derivative of the wild-type strain Z78 (13). RAM4 is a strain tagged with the dsred gene, which expresses the red fluorescent protein, to allow the monitoring of single bacterial cells in $P$. vulgaris roots (10). Seeds of $P$. vulgaris (cv. Uirapuru) were surface-sterilized with $70 \%$ ethanol (J.T. Baker, Mexico) for $5 \mathrm{~min}$ and shaken in a $2 \%$ sodium hypochlorite (Bond

Correspondence: R.A. Monteiro, Departamento de Bioquímica e Biologia Molecular, Universidade Federal do Paraná, 81531-990 Curitiba, PR, Brasil. E-mail: roseadele@ufpr.br

Received June 16, 2010. Accepted December 15, 2010. Available online January 14, 2011. Published March 7, 2011. 
Carneiro, Brazil) containing 0.02\% Tween-20 (United States Biochemical, USA) solution for $20 \mathrm{~min}$ at $30^{\circ} \mathrm{C}$. Seeds were then washed five times with sterile distilled water by shaking for 15 min each time and germinated at $25^{\circ} \mathrm{C}$ in the dark for 48 h. $P$. vulgaris roots were then incubated at $30^{\circ} \mathrm{C}$ for $15 \mathrm{~min}$ with $6 \times 10^{8}$ colony forming units (CFU)/mLSMR1 (wild-type) or RAM4 (dsred) grown in NFbHPN medium (14). After incubation, the plantlets were placed in wells of a 96-well block containing filter paper soaked with plant medium (15) and incubated for a 14-h light period at $25^{\circ} \mathrm{C}$.

The roots of 3-day-old plantlets of $P$. vulgaris were analyzed at $0,3,7$, and 9 days after inoculation with $6 \times 10^{8}$ $\mathrm{CFU} / \mathrm{mL} H$. seropedicae strain SMR1. After these intervals, approximately $0.05 \mathrm{~g}$ fresh roots was surface-sterilized by sequentially washing with $70 \%$ ethanol ( $1 \mathrm{~min}$ ), $1 \%$ sodium hypochlorite containing $0.01 \%$ Tween-20 (1 $\mathrm{min}$ ) and three times with sterile water (5 min). The roots were homogenized using a sterile pestle and mortar, and the extracts diluted in $1 \mathrm{~mL}$ sterile saline $(0.9 \% \mathrm{NaCl})$. The diluted extracts were plated onto solid NFbHPN medium in the absence or presence of $80 \mu \mathrm{g} /$ $\mathrm{mL}$ streptomycin (Sigma, USA). The number of CFU was determined after 24-48 h of incubation at $30^{\circ} \mathrm{C}$. The identity of the recovered bacteria was determined by amplification and sequencing of the 16SrRNA gene (16).

The colonization pattern of $P$. vulgaris roots by $H$. seropedicae was observed by inoculating $P$. vulgaris roots with the RAM4 strain followed by confocal microscopy. Root samples were collected 1, 2 or 3 days after inoculation, washed with water, hand cut, mounted on a microscope slide and immediately examined under a BioRad Confocal Radiance 2001-Eclipse E800 Nikon Microscope (USA) equipped with an HeNe laser (DsRed: excitation, $543 \mathrm{~nm}$; emission filter LP, $560 \mathrm{~nm}$ ).

We measured the dry weight of inoculated plants grown in medium containing $0,0.2$, and $4 \mathrm{mM}$ ammonium nitrate (Merck, Germany) and compared it to that of non-inoculated plants grown in the same medium. The bean seeds were sterilized, germinated and inoculated as described above. Ten days after inoculation the roots were dried and the weight was determined.

\section{Results}

The results indicated that $H$. seropedicae colonized $P$. vulgaris roots progressively from the first to the 9th day after inoculation. The number of bacteria recovered from surface sterilized roots increased from $4 \times 10^{4}$ per gram fresh root 3 days after inoculation to $4 \times 10^{6}$ bacteria 9 days after inoculation (Figure 1). To confirm that the recovered bacteria were indeed $H$. seropedicae, the 16SrRNA gene of randomly selected colonies was amplified and sequenced. All sequences were $100 \%$ identical to those of $H$. seropedicae SMR1.

Under the confocal microscope $H$. seropedicae expressing the DsRed protein showed bright red fluorescence, easily distinguishable from the diffuse fluorescence background of the contour of the plant cells. After 15 min of incubation with the RAM4 strain, cell clusters were found on the root hairs (Figure 2). These are probable entry sites used by the bacteria, possibly due to a higher concentration of carbon sources at these points (17).

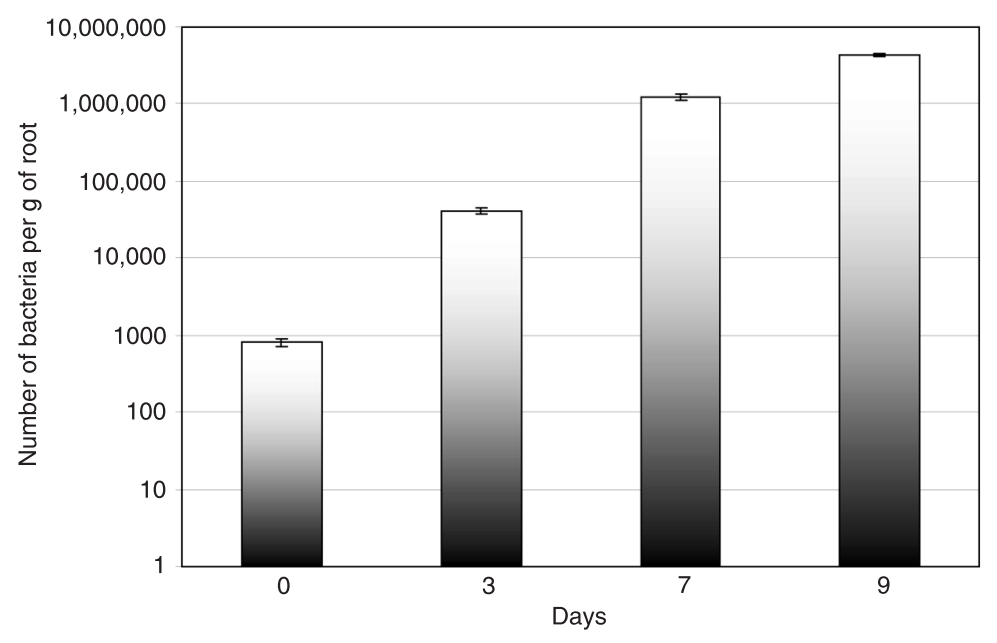

Figure 1. Internal colonization of Phaseolus vulgaris roots by Herbaspirillum seropedicae. The extent of internal colonization was determined $15 \mathrm{~min}$ after inoculation (day 0 ) and on days 3, 7, and 9. Data are reported as CFU/g (mean $\pm \mathrm{SD}$ ) fresh roots from 3 plants per treatment.
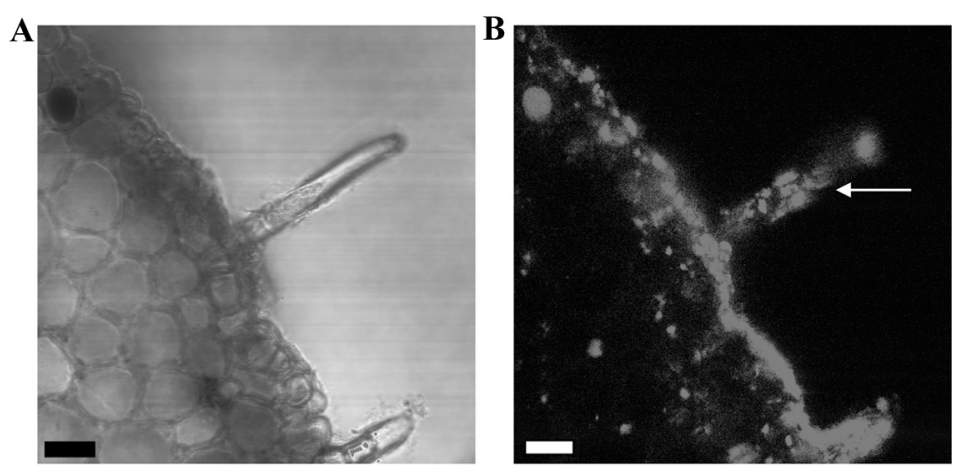

Figure 2. Photomicrographs of a cross-section of Phaseolus vulgaris root $15 \mathrm{~min}$ (A, B) after inoculation with Herbaspirillum seropedicae strain RAM4. Left, Transmitted light microscopy. Right, Confocal fluorescence microscopy. Arrow shows bacteria accumulating in the lateral root. Magnification bars: $15 \mu \mathrm{m}$. 


\section{$24 \mathrm{~h}$ after inoculation}

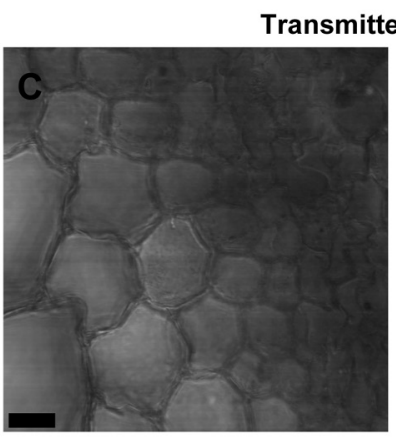

a

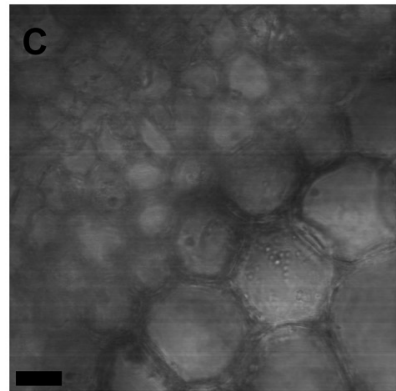

b

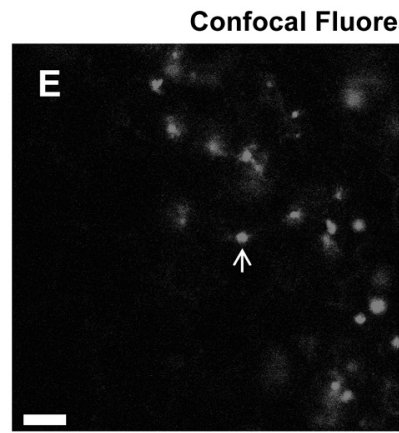

C

\section{$72 \mathrm{~h}$ after inoculation}

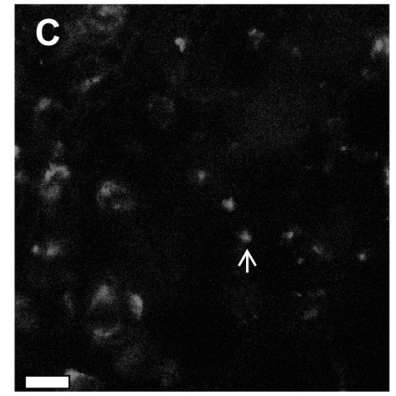

d

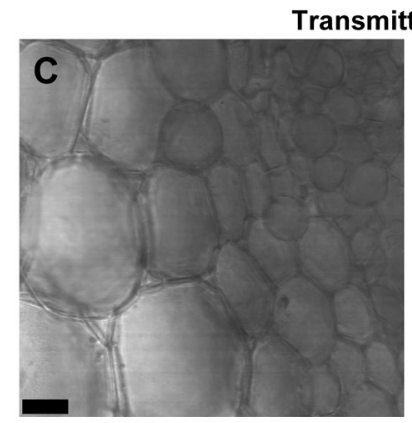

e

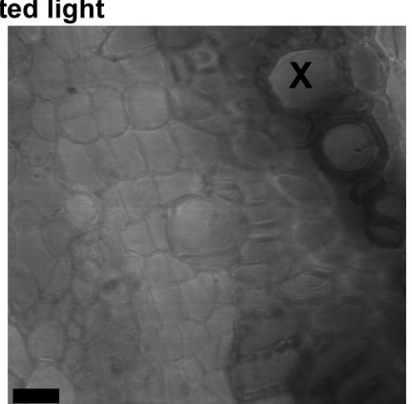

f

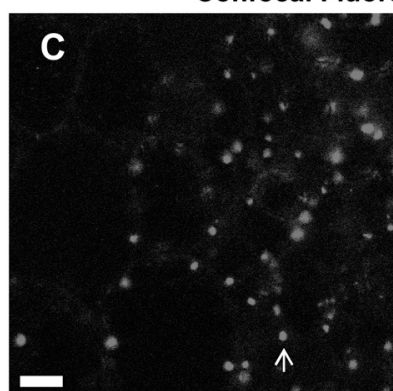

g

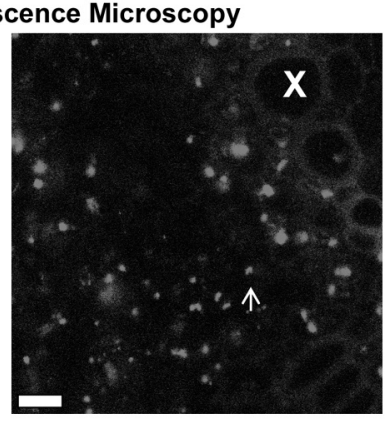

h

Figure 3. Transmitted light and confocal fluorescence microscopy of a cross-section of Phaseolus vulgaris root 24 (a-d) or $72 \mathrm{~h}$ (e-h) after inoculation with Herbaspirillum seropedicae strain RAM4. The images were recorded in two different regions of the cross-section, i.e., the epidermis (a, c, e, and g) and the central cylinder (b, d, f, and h). Transmitted light microscopy (a, b, e, and f); confocal fluorescence microscopy (c, d, g, and $\mathrm{h}$ ). $\mathrm{C}=$ cortex; $\mathrm{E}=$ epidermis; $\mathrm{X}=$ xylem vessels. Arrows indicate the fluorescent bacteria. Magnification bars $=50 \mu \mathrm{m}$.

Confocal microscopy images of different regions of a cross-section of $P$. vulgaris roots inoculated with RAM4 showed that the bacteria had started to invade the root internal tissues $24 \mathrm{~h}$ after inoculation. After $72 \mathrm{~h}$ the number of bacterial cells increased progressively from the epidermis to the central cylinder (Figure 3).

To investigate the effect of $H$. seropedicae on $P$. vulgaris growth, plantlets were incubated for $15 \mathrm{~min}$ with $1 \mathrm{~mL}$ of a fresh culture containing $10^{8} \mathrm{CFU}$, and transplanted to vermiculite in the presence of different $\mathrm{NH}_{4} \mathrm{NO}_{3}$ concentrations. After 10 days, the dry weight of the inoculated plants was significantly lower than that of the non-inoculated plants under all conditions (Table 1), suggesting that $H$. seropedicae has a negative effect on the growth of $P$. vulgaris (cv. Uirapuru).

\section{Discussion}

The results showed that $H$. seropedicae is able to adhere to and colonize $P$. vulgaris roots internally. $H$. lusitanum was also recovered from bean roots 2 weeks
Table 1. Dry weight of Phaseolus vulgaris roots inoculated or not with Herbaspirillum seropedicae SMR1.

\begin{tabular}{lcc}
\hline $\mathrm{NH}_{4} \mathrm{NO}_{3}(\mathrm{mM})$ & \multicolumn{2}{c}{ Dry weight $(\mathrm{g})$} \\
\cline { 2 - 3 } & Inoculated & Uninoculated \\
\hline 0.0 & $11.8 \pm 2.5$ & $28.2 \pm 7.7^{*}$ \\
0.2 & $31.8 \pm 1.2$ & $41.6 \pm 4.7^{*}$ \\
4.0 & $35.6 \pm 9.5$ & $58.2 \pm 2.6^{*}$ \\
\hline
\end{tabular}

Data are reported as means \pm SD for 3 plants per treatment. Plants were grown without nitrogen or in the presence of 0.2 or $4 \mathrm{mM} \mathrm{NH}_{4} \mathrm{NO}_{3}$ and analyzed 10 days after inoculation. The total dry weight of bean roots inoculated or not with $\mathrm{H}$. seropedicae SMR1 is shown. * $\mathrm{P}<0.05$ compared to inoculated (Student $t$ test).

after inoculation (12).

The $H$. seropedicae colonization process on and in $P$. vulgaris roots appears to occur in a pattern similar to that 
of Poaceae $(9,10)$ : the bacteria invade the intercellular spaces and disperse in the cortex, eventually reaching the xylem vessels. A notable difference was a lower number of bacterial cells visualized at the time tested, when compared with that of maize (10).

We also evaluated the effect of $H$. seropedicae inoculation on the growth of common bean seedlings (Table 1). The result showed that $H$. seropedicae has a negative effect on Phaseolus growth, since the root dry weights of plants inoculated with $\mathrm{H}$. seropedicae were lower than those of uninoculated plants. This is in contrast to the growth-promoting effect of $H$. seropedicae on rice plants (9), indicating that $H$. seropedicae has different effects on different plants. A strong interaction between the plant genotype and the rhizobacteria inoculated has been documented, with effects ranging from variable growth promotion $(18,19)$ to

\section{References}

1. Baldani JI, Baldani VLD, Seldin L, Döbereiner J. Characterization of Herbaspirillum seropedicae gen. nov., sp. nov., a new root-associated nitrogen-fixing bacterium. Int J Syst Bacteriol 1986; 36: 86-93.

2. Baldani JI, Baldani VLD, Sampaio MJAM, Döbereiner J. A fourth Azospirillum species from cereal roots. An Acad Bras Cienc 1984; 56: 365.

3. Boddey RM, Oliveira OC, Urquiaga S, Reis VM, Olivares FL, Baldani VLD, et al. Biological nitrogen fixation associated with sugar cane and rice: contributions and prospects for improvement. Plant Soil 1995; 174: 195-209.

4. Cruz LM, Souza EM, Weber OB, Baldani JI, Döbereiner J, Pedrosa FO. 16S ribosomal DNA characterization of nitrogenfixing bacteria isolated from banana (Musa spp) and pineapple (Ananas comosus (L.) Merril). Appl Environ Microb 2001; 67: 2375-2379.

5. Weber OB, Baldani VLD, Teixeira KRS, Kirchhof G, Baldani $\mathrm{JI}$, Döbereiner J. Isolation and characterization of diazotrophic bacteria in banana and pineapple plants. Plant Soil 1999; 210: 103-113.

6. Bashan Y, Holguin G, de-Bashan LE. Azospirillum-plant relationships: physiological, molecular, agricultural, and environmental advances (1997-2003). Can J Microbiol 2004; 50: 521-577.

7. Baldani JI, Pot B, Kirchhof G, Falsen E, Baldani VL, Olivares FL, et al. Emended description of Herbaspirillum; inclusion of [Pseudomonas] rubrisubalbicans, a milk plant pathogen, as Herbaspirillum rubrisubalbicans comb. nov.; and classification of a group of clinical isolates (EF group 1) as Herbaspirillum species 3. Int J Syst Bacteriol 1996; 46: 802-810.

8. James EK, Gyaneshwar P, Mathan N, Barraquio WL, Reddy PM, lannetta PP, et al. Infection and colonization of rice seedlings by the plant growth-promoting bacterium Herbaspirillum seropedicae Z67. Mol Plant Microbe Interact 2002; 15: 894906.

9. Roncato-Maccari LD, Ramos HJ, Pedrosa FO, Alquini Y, Chubatsu LS, Yates MG, et al. Endophytic Herbaspirillum seropedicae expresses nif genes in gramineous plants. FEMS Microbiol Ecol 2003; 45: 39-47.

10. Monteiro RA, Schmidt MA, Baura VA, Balsanelli E, Wassem $R$, Yates MG, et al. Early colonization pattern of maize (Zea mays L. Poales, Poaceae) roots by Herbaspirillum seropedicae a slight reduction in yield $(20,21)$. The negative effect of $H$. seropedicae on the growth of Phaseolus may be due to interaction between the plant and bacterial molecular factors such as those secreted by the type three secretion system (T3SS) of $H$. seropedicae. In Rhizobium NGR234, the inactivation of T3SS leads to an increase in the number of root nodules in $P$. vulgaris cv. BAT93, suggesting that the secretion of certain effector proteins may negatively affect the interaction with Rhizobium NGR234 (Lariguet P, unpublished results).

The present results show that $H$. seropedicae is not an exclusive endophyte of gramineous plants, but is capable of colonizing other plant types such as the common bean, indicating that $H$. seropedicae is a broad host-range endophyte. Whether this association benefits the development of common beans under specific conditions is yet to be established.
(Burkholderiales, Oxalobacteraceae). Genet Mol Biol 2008; 31: 932-937.

11. Olivares FL, Baldani VLD, Reis VM, Baldani JI, Döbereiner J. Occurrence of endophytic diazotrophs Herbaspirillum spp. in roots, stems and leaves predominantly of Gramineae. Biol Fert Soils 1996; 21: 197-200.

12. Valverde A, Velazquez E, Gutierrez C, Cervantes E, Ventosa A, Igual JM. Herbaspirillum lusitanum sp. nov., a novel nitrogenfixing bacterium associated with root nodules of Phaseolus vulgaris. Int J Syst Evol Microbiol 2003; 53: 1979-1983.

13. Pedrosa FO, Teixeira KRS, Machado IMP, Steffens MBR, Klassen G, Benelli EM, et al. Structural organization and regulation of the nif genes of Herbaspirillum seropedicae. Soil Biol Biochem 1997; 9: 843-846.

14. Klassen G, Pedrosa FO, Souza EM, Funayama S, Rigo LU. Effect of nitrogen compounds on nitrogenase activity in Herbaspirillum seropedicae SMR1. Can J Microbiol 1997; 43: 887-891.

15. Broughton WJ, Dilworth MJ. Control of leghaemoglobin synthesis in snake beans. Biochem J 1971; 125: 1075-1080.

16. Magnani GS, Didonet CM, Cruz LM, Picheth CS, Pedrosa FO, Souza EM. Diversity of endophytic bacteria in Brazilian sugarcane. Genet Mol Res 2010; 9: 250-258.

17. Bennett RA, Lynch JM. Bacterial growth and development in the rhizosphere of gnotobiotic cereal plants. J Gen Microbiol 1981; 125: 95-102.

18. Roesch LFW, Camargo FAO, Selbach PA, Sá ELS, Passaglia LMP. Identificação de cultivares de milho eficientes na absorção de nitrogênio e na associação com bactérias diazotróficas. Cienc Rural 2005; 35: 924-927.

19. Baldani VLD, Baldani JI, Döbereiner J. Inoculation of rice plants with endophytic diazotrophs Herbaspirillum seropedicae and Burkholderia spp. Biol Fertil Soil 2000; 30: 485-491.

20. Didonet AD, Lima OS, Candaten AA, Rodrigues O. Realocação de nitrogênio e de biomassa para os grãos, em trigo submetido a inoculação de Azospirillum. Pesq Agropec Bras 2000; 35: 401-411.

21. Garcia de Salomone I, Döbereiner J. Maize genotype effects on the response to Azospirillum inoculation. Biol Fertil Soil 1996; 21: 193-196. 